\title{
Osmanlı Devleti'nin Son Dönemlerinde Gayrimüslim Mektepler Yararına Düzenlenen Piyangolar
}

\author{
Emine Gümüşsoy*
}

(ORCID: 0000-0002-1401-8493)

\author{
Makale Gönderim Tarihi \\ 22.01.2021
}

Makale Kabul Tarihi

16.03.2021

\section{Atıf Bilgisi/Reference Information}

Chicago: Gümüşsoy, E., “Osmanlı Devleti'nin Son Dönemlerinde Gayrimüslim Mektepler Yararına Düzenlenen Piyangolar", Vakanüvis-Uluslararası Tarih Araştırmaları Dergisi, 6/1 (2021): 178-206.

APA: Gümüşsoy, E. (2021). Osmanlı Devleti'nin Son Dönemlerinde Gayrimüslim Mektepler Yararına Düzenlenen Piyangolar. Vakanüvis-Uluslararası Tarih Araştırmaları Dergisi, 6 (1) , 178-206.

Öz

Osmanlı Devleti'nin son dönemlerinde Avrupa kaynaklı olarak öncelikle levantenler ve gayrimüslim tebaa arasında başlayan piyangonun ilk örneklerinden birisi de mektepler yararına düzenlenenler olmuştur. İstanbul ve taşradaki gayrimüslim mekteplerin intiyaçları ve masrafları gerekçe gösterilerek düzenlenen piyangolara belirlenen şartları taşımak koşuluyla izin verilmiştir. Mektebin resmî ruhsatının bulunması başta olmak üzere piyangoya konulacak eşya miktarı ve kıymeti, ne kadar bilet basılacağı gibi belirlenen hususlara uyulması istenmiştir. Çekilişe devletin bir görevlisinin nezaret etmesi gibi her aşamada bir kontrol söz konusu olmakla birlikte bu piyangolar mektepler için bir gelir kaynağı haline gelmiştir. Çalışmamızda Osmanlı arşiv belgelerinden hareketle söz konusu süreç örnekleriyle birlikte ele alınmıştır.

Anahtar Kelimeler: Osmanlı Devleti, piyango, mektep, talebe, çekiliş.

* Doç.Dr., Eskişehir Osmangazi Üniversitesi Fen-Edebiyat Fakültesi Tarih Bölümü, egumussoy@ogu.edu.tr.

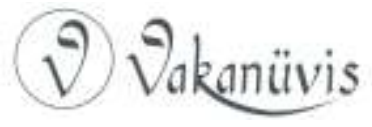




\title{
Lotteries Introduced On Behalf of the Non-Muslim Schools in the Late Period of Ottoman Empire
}

\begin{abstract}
The late Ottoman era witnessed the emergence of the lotteries of European origin which were particularly widespread among the non-Muslims and Levantines. One of the first examples of these lotteries was implemented for the benefit of non-Muslim schools. The activities of lotteries held in İstanbul and in the countryside and aimed at meeting the needs and expenses of nonMuslim schools were allowed on condition of providing the necessary rules. The schools were asked to be equipped with an official license and observe other rules concerning the value and volume of the merchandise as well as the amount of the tickets. The process of lottery was checked at any stage. The very moment of drawing, for example, was accompanied by an official representative but the lotteries still became a source of revenue for the schools. In this research, the process of lottery drawing in late Ottoman Empire would be examined according to Ottoman archival sources.
\end{abstract}

Keywords: Ottoman State, lottery, school, pupil, draw

\section{Giriş}

"Piyango" yada "Lotarya" sözcüğünün Osmanlı kaynaklarında ilk olarak Ebubekir Ratip Efendi'nin 1792 tarihli Nemçe Sefaretnamesi'nde geçtiği varsayılmaktadır. ${ }^{1}$ Nitekim Avrupa menşeli bir kelime ve uygulama olan piyango/lotarya; şans, rastlantı ve olasılık gibi anlamlar barındırmaktadır.

"Her ne nam altında olursa olsun, baht ve talih yoluyla bir şey kazanmak ümidi uyandırılmak suretiyle, halka arzedilen muamele" 2 anlamına gelen piyangonun eşya, para ve yardım piyangoları olmak üzere pek çok farklı uygulama şekli söz konusudur.

Ebuzziya Tevfik "Piyango" başlıklı yazısında; Paris, Viyana ve Berlin sokaklarının duvarlarında senenin pek çok günü piyango ilânlarından

\footnotetext{
${ }^{1}$ Ebubekir Ratib Efendi, Cenova usulü piyangoyu detaylarıyla anlatırken Avusturya'nın bu işten ciddî bir gelir elde ettiğini kaydetmiştir. Ayrıntılı bilgi için bkz. Fatih Yeşil; Aydınlanma Çağında Bir Osmanlı Kâtibi Ebubekir Ratib Efendi(1750-1799), İstanbul, 2010, s.361-362.

2 Mete Tunçay, Türkiye'de PiyangoTarihi ve Millî Piyango Idaresi, Ankara, 1993, s.11.
}

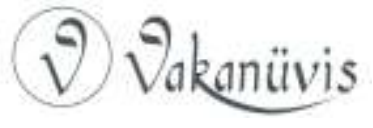


başka bir şey görülmediğini, bazı ilânlarda piyangonun bir mekteb, bir hastane veya hayırlı bir iş için olduğuna dair açıklamalar olduğunu belirtir. Ona göre "piyangoların rulet yani fırıldak oyunu kadar tehlikeli olduğundan şüphe edilmemelidir. Piyango düzenleneceği vakit ihtiyatı elden bırakmamak, imtiyaz verilecek şahıs veya kurumları incelemek gerekmektedir". ${ }^{3}$

Osmanlı Devleti'nde piyango ile ilgili ilk uygulamalar levantenler ve gayrimüslim tebaa arasında başlamıştır. Örneğin, 1852'de 10 yıl tiyatro oynatma tekeli alan Naum Efendi, tiyatrosunun geliri giderini karşılamadığından, müşteri çekebilmek için 1200 piyango bileti bastırarak kazanan 100 bilete (40 loca ve 60 sandalye) mevsimlik oyun izleme imkânı vadetmiştir. ${ }^{4}$ Benzer şekilde Gedikpaşa Tiyatrosu'na müşteri çekebilmek için de tiyatro biletleri üzerinden bir eşya piyangosu düzenlenmiştir. 1856'da Ermeni Katolik kilisesinin kefaletiyle düzenlenen karma eşya ve para piyangosu da bir başka örnektir. ${ }^{5}$

Gayrimüslim tebaa arasında bir süre sonra mektep, hastane ve yetimhane gibi eğitim, sağlık ve sosyal yardım içerikli piyangolar da düzenlenmeye başlamış ve giderek yaygınlaşmıştır.

\section{Gayrimüslim Mekteplerin İşleyişi}

Osmanlı Devleti'nde "azınlık ve yabancı okulları" olarak da adlandırılan gayrimüslim mekteplerinin sayısı 18. yüzyıldan itibaren artmaya başlamış, 19. yüzyıl ortalarında hemen hemen her bölgeye yayılmıştır. Gayrimüslimlere ve yabancı devletlere tanınan haklar suiistimal edilerek kullanıldığı gibi birbirlerine de örnek teşkil etmişlerdir. Kanuni esneklik ve boşluklardan yararlanarak önce mektebi açıp sonra intiyaç duyduklarında ruhsat isteme yoluna gitmişlerdir. Bulgar ahalisinden kimsenin bulunmadığı Kesriye'de bir Bulgar mektebi açılması gibi ihtiyaç olup olmadığına bakmadan siyasi açıdan gerekli gördükleri yerlerde mektepler açmışlardır. ${ }^{6}$

\footnotetext{
${ }^{3}$ Ebuzziya Tevfik, "Piyango", Mecmua-yı Ebuzziya, Gurre-i Safer 1300, c.3, N.27, s.838

4 BOA. I.HR 113/5514 (4 Şaban 1270/6 Kasım 1853)

${ }^{5}$ Tunçay, a.g.e, s.29-30.

6 İlknur Polat Haydaroğlu, Osmanlı Imparatorluğu'nda Yabancı Okullar, Kültür Bakanlığı Yayını, Ankara, 1990, s. 16-17.
}

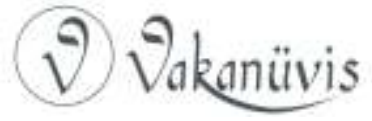


Bu süreçte yaklaşık 900 mektebin farklı ve kritik bölgelerde açıldığı görülmektedir. Açtıkları veya açtırdıkları mektepler ile yabancı devletler de kendi amaçları doğrultusunda faaliyetlerine devam etmişlerdir. Nitekim mektep yöneticileri ve öğretmenlerin belirlenmesinde de bu devletlerin misyoner teşkilatları etkili olmuştur. ${ }^{7}$

1869 Maarif-i Umumiye Nizamnamesi'ne kadar bu mekteplerin açוlış ve işleyiş̧ini düzenleyen hukukî düzenlemelerin bulunmaması nedeniyle büyük ölçüde bir keyfîlik söz konusu olup çoğunun ruhsatı bulunmamaktadır. Bu arada Islahat Fermanı ile her cemaatin mektep açma yetkisini alması da pek çok yabancı devleti mektep açmaya sevk etmiştir. ${ }^{8}$ Mekteplerin açılışında dinî faktörler dışında bölgede söz sahibi olma düşüncesi de ön plândadır.

1869 nizamnamesinin 129. maddesinde cemaatler ve yabancı devlet tebaası tarafından ücretli veya ücretsiz olarak açılan mekteplerin masraflarının kurucuları veya bağı oldukları vakıfları tarafından karşılanacağı belirtilmiştir. Mektep hocalarının diploma sahibi olmaları, okutulacak derslerin de Maarif Nezaretince onaylanmış olması gibi şartlar ileri sürülmüştür. ${ }^{9}$

Öte yandan Nizamname ile mektep açabilmek için ruhsat şartı getirilmiştir. Ruhsat başvurusunun merkezde Maarif Nezaretine, taşrada ise yerel maarif idarelerine yapılması istenmiştir. Başvuruda bulunanların gerekli soruşturma ve incelemeler yapıldıktan sonra uygun görülürse ruhsat işlemi tamamlanmıştır. ${ }^{10}$

Osmanlı Devleti bünyesinde açılan gayrimüslim mektepleri kendi ruhani meclisleri ve kiliseleri tarafından desteklenmektedir. Nizamname doğrultusunda ilkokul seviyesinde açılan gayrimüslim mektepleri genellikle kilise müştemilatında, orta ve yüksekokul seviyesinde olanlar ise kilise dışında faaliyetlerine devam etmiştir. ${ }^{11}$

\footnotetext{
7 Hidayet Vahapoğlu, Osmanlı'dan Günümüze Azınlık ve Yabancı Okulları (Yönetimleri Açısından), Ankara, 1990, s.75.

8 Vahapoğlu, a.g.e, s.69-70.

${ }^{9}$ Haydaroğlu, a.g.e, s.28-29.

${ }^{10}$ Haydaroğlu, a.g.e, s.42-43.

11 Vahapoğlu, a.g.e, s.65.
}

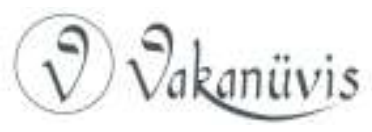


Söz konusu mekteplerle ilgili yapılan değişiklikler sırasında "Mekâtibi Gayrimüslim ve Ecnebiye Müfettişliği" de ihdas edilmiştir. Görevi; mektep ve öğretmenlerin denetlenmesinin yanı sıra mekteplere zararlı yayınların sokulmasını engellemek ve düzenlenen piyangolara nezaret etmekti. ${ }^{12}$

Gayrimüslim mekteplerin gelir kaynakları; bağlı bulundukları devlet ve kurumlardan aldıkları yardımlar, bağışlar, öğrencilerden alınan harçlar ve Osmanlı Devleti'nden alınan ödeneklerdi. Örneğin, II.Mahmud döneminde Rum mekteplerine 20.000, Ermeni mekteplerine 7.500, Yahudi mekteplerine 7.500, ve Katolik mekteplerine 5.000 kuruş ödenek ayrılmıştır. ${ }^{13}$

Mektepler gelir kaynakları yetmediğinde çeşitli ek kaynaklar bulma yoluna gitmişlerdir. Bunlardan birisi balo düzenlemek iken daha sonra talebelerin el işlerinin konulduğu piyango çekilişleri de yaygınlık kazanmıştır.

\section{Gayrimüslim Mektepler Yararına Piyango Düzenlenmesi}

Gayrimüslim mekteplerinin masrafları ve ihtiyaçları için piyango düzenlenmesi sıklıkla karşılaşılan bir durum olup zamanla sürekli hale gelmiş ve gelir kaynaklarından birisi olarak görülmüştür.

Mektep yararına düzenlenecek piyango için öncelikle izin alınması gerekliydi. İzin için ruhani lider, mütevelli, cemaat mensupları ya da mektep müdür veya idarecilerinden birisinin başvuruda bulunması yeterliydi. Örneğin, Edirne'de Yıldırım isimli mevkii ile Kaleiçi'nde bulunan Rum ve Ermeni mektepleri yararına 50.000 kuruşa kadar bir piyango çekilişi için Rum metropolitliği ve Ermeni murahhaslığı tarafından başvuruda bulunulmuştur ${ }^{14}$ Bir başka örnekte ise geliri Beyoğlu Rum kız mektebine kalmak üzere talebenin el işlerinden bir piyango düzenlenmesi için mektep mütevellileri tarafından yapılan başvuru sonucu 7 Mayıs 1893 günü mektep salonunda çekiliş yapılması

\footnotetext{
12 Vahapoğlu, a.g.e, s. 128-129.

${ }^{13}$ Haydaroğlu, a.g.e, s.76,80.

14 BOA. MV 76/42 (7 Rebiülevvel 1311/18 Eylül 1893)
} 
kararlaştırılmıştır. ${ }^{15}$ Beykoz kazası Arnavud karyesinde bulunan Rum kız ve erkek mekteplerinin ihtiyaçlarını karşılamak üzere çekilecek piyango için ise Kadıköy Rum metropolitliği başvuruda bulunmuştur. ${ }^{16}$

Söz konusu izin talepleri ile ilgili farklı milletlere ait birçok örnek bulunmaktadır. Rumlar bu konuda ilk sırada yer almaktadır. Örneğin, Tekfurdağı Rum mekteplerinin ihtiyaçları için piyango düzenlenmesi konusunda Tekfurdağı Metropolitliği başvuruda bulunmuştur. ${ }^{17}$ Silivri'nin Bigados karyesinde bulunan Rum kız mektebi yararına düzenlenecek piyango için ise Rum metropolidi başvuruda bulunmuştur. ${ }^{18}$ Salma Tomruk Rum kilisesine mensup kız ve erkek mektebi yararına bir piyango düzenlenmesi için kilise ileri gelenleri Maarif Nezaretine müracaatta bulunmuşlar ancak piyango çekilişinde kimlerin hazır bulunacağı, biletlerin nerede basılacağı ve gerçekten ihtiyaçlarının bulunup bulunmadığı bilinmediği için izin verilmemiştir. ${ }^{19}$

Bir başka örnekte, Hasköy'de bulunan Musevi mektepleri yararına her bir numarası kazanacak şekilde bir piyango çekilişi yapılması için cemaatten Marko ve 2 arkadaşının verdiği dilekçe üzerine bu tür işlere izin verilmekle birlikte piyangoya ne miktar eşya konulacağı, değeri ve diğer şartların belirlenmesi sonucu karar verilebileceği belirtilmiştir. ${ }^{20}$ Bunun üzerine piyangoya konulacak eşyanın 8.550 parça ve 30.138 kuruş değerinde olduğu, 5'er kuruşluk biletler ile 12.612 kuruş gelir elde edilmesinin hedeflendiği ifade edilmiştir. Bu bilgilendirmeden sonra piyango için izin verilmiştir. ${ }^{21}$ Benzer şekilde İzmir'de bulunan Musevi mektebi yararına bir piyango düzenlenmesi için izmir hahambaşı kaymakamlığı tarafından bir başvuruda bulunmuştur. ${ }^{22}$

\footnotetext{
${ }^{15}$ BOA. MF.MKT 158/39 (22 Cemaziyelahir 1310/11 Ocak 1893)

${ }^{16}$ BOA. DH.TMIK.M 181/12 (22 Cemaziyelahir 1322/3 Eylül 1904)

17 BOA. MF.MKT 358/27 (19 Muharem 1315/20 Haziran 1897)

18 BOA. MF.MKT 1007/60 (5 Cemaziyelahir 1325/16 Temmuz 1907)

${ }^{19}$ BOA. ZB 28/6 (9 Cemaziyelahir 1323/11 Ağustos 1905)

20 BOA. MV 38/27 ( 8 Rebiülahir 1306/12 Aralık 1888)

${ }^{21}$ BOA. MV 47/31 (8 Muharrem 1307/4 Eylül 1889)

22 BOA. MV 57/52 (6 Safer 1308/21 Eylül 1890)
}

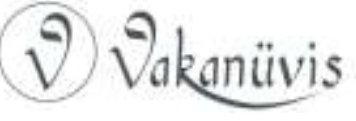


Ermeni Katolik cemaati rahibeleri tarafından idare edilen fukara kız mektepleri yararına düzenlenecek piyangoya ruhsat verilmesi için ise Ermeni patrikliği tarafından izin talep edilmiştir. ${ }^{23}$

İzin başvurusundan sonra inceleme başlatılarak öncelikle mektebin ruhsatının olup olmadığı araştırılmaktadır. Nitekim İstanbul ve taşrada bulunan gayrimüslim ve yabancı mektepleri yararına düzenlenecek balo, tiyatro ve piyango çekilişleri için resmî ruhsatlarının olması, ruhsatı olmayanlara izin verilmeyeceği ifade edilmiştir. Bu arada "Cemaat-i Milliye ve Müessesat-ı Hayriye" namına düzenlenecek piyangolarda 50.000 kuruşa kadar olanların bağıı bulundukları vilayetten aldıkları izin yeterli görülmüştür. Nitekim Kayseri Ermeni kız mektebinin ihtiyaçları için 10'ar kuruşluk 500 adet bilet basılarak düzenlemek istedikleri piyango için yaptıkları başvuruda Ankara vilayetinin yapacağı inceleme sonucu vereceği kararın yeterli olduğu bildirilmiştir. ${ }^{24}$

Öte yandan 50.000 kuruşu geçen piyangolarda durumun Babaıali'ye bildirilerek Sadaretten verilen karar doğrultusunda hareket edilmesi gerekli görülmüştür. ${ }^{25}$

İzin ile birlikte piyangoya konulacak el işlerinin değerinin piyango miktarının dörtte biri derecesinde olması gerekli görülmüştür. Örneğin, 10.000 kuruşluk bir piyangoya ruhsat verilmesi için piyangoya konulacak eşyaların kıymetinin mutlaka 2.500 kuruş olması gereklidir. ${ }^{26} \mathrm{Bu}$ çerçevede alâ, evsat ve edna olarak derecelendirilerek 4.000 kuruş değer biçilen el işleri ve eşyalar için 16.000 kuruş karşılığında bir piyango düzenlenmesi uygun görülmüştür. ${ }^{27}$ Hasköy kız Rum mektebinin yararına 49 parça el işlerinden 2.758 kuruşa karşılık olmak üzere alâ, evsat ve edna olmak üzere üçe ayrılan el işlerinin adet ve fiyatlarını gösteren cetvel de bu konuya ayrıntılı bir örnektir. ${ }^{28}$

\footnotetext{
23 BOA. MV 54/1 (26 Ramazan 1307/16 Mayıs 1890)

24 BOA. MF.MKT 115/26 (21 Cemaziyelevvel 1307/13 Ocak 1890)

25 BOA. DH.HMŞ 16/73 (20 Rebiülevvel 1330/9 Mart 1912)

${ }^{26}$ BOA. MF.MKT 262/38 (21 Zilkâde 1312/16 Mayıs 1895)

27 BOA. MF.MKT 563/28 (24 Safer 1319/12 Haziran 1901)

${ }^{28}$ BOA. MF.MKT 346/50 (30 Receb 1314/4 Ocak 1897)
}

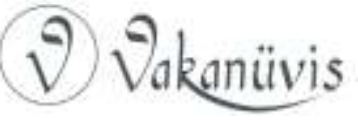


Tablo 1. Hasköy Rum Mektebi Yararına Düzenlenecek Piyangoya Konulacak El İşlerinin Adet ve Fiyatlarını Gösteren Cetvel ${ }^{29}$

\begin{tabular}{|c|c|c|c|}
\hline $\begin{array}{c}\text { Eşyanın cinsi } \\
\begin{array}{c}\text { Beyaz iplikli } \\
\text { yasdık }\end{array}\end{array}$ & Adet & Değeri (kuruş) & Toplam (kuruş) \\
\hline Gömlek & 27 & 108 & 648 \\
\hline Daire & 2 & 40 & 675 \\
\hline Gemi lengeri & 2 & 60 & 80 \\
\hline Mendil için askı & 4 & 30 & 120 \\
\hline $\begin{array}{c}\text { Yün ipeğinden } \\
\text { halı }\end{array}$ & 3 & 70 & 210 \\
\hline Ipek yasdık & 2 & 110 & 220 \\
\hline Kandıru bandırası & 1 & 40 & 40 \\
\hline Dizlik & 1 & 15 & 15 \\
\hline $\begin{array}{c}\text { Çukadan memul } \\
\text { köşse }\end{array}$ & 1 & 30 & 30 \\
\hline & 49 & & 2758 \\
\hline
\end{tabular}

Öte yandan piyangoya konulacak eşyanın cinsi, miktarı ve kıymetini gösteren bir defterin hazırlanması ve eşyalardan birkaç numunenin gönderilmesi gereklidir. ${ }^{30}$ Örneğin, Muş kasabasında bulunan Ermeni kız mektebi talebelerinin el işlerinin piyangoya konulması için yapılan başvuruda, mektebin resmî ruhsatının bulunduğu anlaşımakla birlikte piyangoya konulacak eşya miktarı ve mektebin ihtiyaçlarını karşılayıp karşılayamayacağının belirtilmesi istenmiştir. ${ }^{31}$ Büyükçekmece'deki Rum kız mektebi talebelerinin yaptığı iskemle, konsol ve yastık örtüleriyle, gömlek, dantela, kaneviçe, terlik, bardak kapakları, dantelalı don ve gömlek gibi el işlerinden 50 tanesinin piyangoya konulması, 5'er kuruşluk 500 biletin basılmasına mektep mütevellileri tarafından izin talep edilmiştir. ${ }^{32}$

Bir sonraki aşamada piyango için basılan biletlerin Maarif Nezareti'nce onaylanması gerekmektedir. Maarif Nezareti bu sürecin

\footnotetext{
29 BOA. MF.MKT 346/50 (9 Receb 1314/14 Aralık 1896)

30 BOA. DH.TMIK.M 159/9 (22 Ramazan 1321/12 Aralık 1903)

31 BOA. DH.TMIK.M 138/47 (4 Zilkâde 1320/2 Şubat 1903)

32 BOA. MF.MKT 346/35 (28 Receb 1314/2 Ocak 1897)
} 
takipçisi olduğu gibi satılamayan biletlerin de buraya teslim edilmesi istenmiştir. Piyango çekilişlerine Gayrimüslim Mektepleri ve Ecnebiye Müfettişlik İdaresi'nden bir kişinin nezaret etmesi ve çekilişten sonra hesap cetvelinin gönderilmesi gerekli görülmüştür. Örneğin, Ereğlikapı Rum Mektebi yararına düzenlenecek piyango çekilişinde Mekâtib-i Gayrimüslim ve Ecnebiye Müfettişliği İdaresi'nden Nazım Bey'in hazır bulunması ve çekilişten sonra hesap cetvelinin gönderilmesi kararlaştırılmıştır. ${ }^{33}$

Piyango için basılıp satılamayan biletler iade edilecek, iade edilen biletler de uygun bir şekilde imha edilecektir. Nitekim Samatya'da Mirahur mahallesindeki Rum kız mektebi ${ }^{34}$ ve Langa-i Kebir Rum Mektebi yararına düzenlenen piyangoda satılmayan biletler bu şekilde imha edilmiştir. ${ }^{35}$

Bazı çekilişlere ait çok daha ayrıntılı talimatlar hazırlanmıştır. İzmir Musevi yetim mektepleri ve hastaneleri yararına düzenlenen talimatname buna bir örnektir.

“izmir Musevi Yetim Mektebi Ille Hastanesi Piyangosunun Talimatı

1. Biletlerin toplamı 6 bin adet olup bunların tamamı kazanacaktır.

2. Piyango 7 kez çekilecektir. Her bir biletin fiyatı 4 mecîdi olup bedeli çekilişten önce ödenecektir. Biletlerin üzerinde $A B C D E F G H$ harflerinden birisi basılı bulunacaktır.

3. 1. veya diğer çekilişlerden sonra bilet almak isteyenler önce çekiliş yapılan kısımların bedelini ödemeye mecbur olacaklardır.

4. Her çekilişte kazanan numaralar imha edilecektir.

5. Biletler kolektörlerin mağazalarında satışa sunulacaktır. (Çuha Bedesteni 32 numara, Servili Han 6 numara, Girit Hanı 4 numara) Bilet satışları burada yapıldığı gibi ikramiyelerin ödenmesi veya her türlü itiraz için de buraya müracaat edilecektir.

6. Bilet hamiline ait olduğunda ve her kimin elinde bulunursa muteberdir. Zayi edilen bilet çekilişten 3 ay sonrasına kadar kolektöre

\footnotetext{
33 BOA. ZB 29/71 (28 Receb 1323/28 Eylül 1905)

${ }^{34}$ BOA. MF.MKT 928/47 (23 Rebiülevvel 1324/17 Mayıs 1906)

35 BOA. MF.MKT 967/8 (20 Şevval 1324/7 Aralık 1906)
} 
başkası tarafından ibraz olunamadığı takdirde ihbarda bulunan kişiye ikramiye ödenecektir.

7. Kazanan biletlerin ikramiyesinden yüzde 15 düşülerek kalanı mecîdiyeye 20 kuruş hesabıyla sahiplerine verilecek ve ikramiye çekilişten 8 gün sonra ödenecektir.

8. Çekiliş herkese açık olup İzmir Musevi Havra reisi ve bir komisyon huzurunda gerçekleştirilecektir.

9. Bilet alan kişi her çekilişten 3 gün önce biletin bedelini ödemediği takdirde o biletteki hakkını kaybetmiş olacağından bu durumda başkasına satılan biletler için hiçbir itiraz kabul edilmeyecektir.

10. Musevi Yetim Mektebiyle hastanenin mührünü taşımayan biletler geçerli kabul edilmeyecektir.

11. 1'den 6'ya kadar 5 bin kuruşluk ve 7. çekilişin 120 bin kuruşluk mükâfatı en son çıkan numara ve gerek ikramiye olsun ve gerek amorti olsun kazanacaktır." ${ }^{36}$

Piyango için basılan biletlerin sadece ilgili vilayet dahilinde satışına izin verilmiştir. Örneğin, İzmir Musevi yetim mektepleriyle hastanesi düzenlenen piyango biletlerinin Dersaadet Büyük Acentası (Küçük İsmail Paşa Hanı 8 numarada)nda, İstanbul Balık Pazarı Suşehri Hanı 126 numarada, Galata Havyar Hanı 69 ve 79 numarada ve ayrıca Galata ve İstanbul'da çeşitli sarrafların dükkanlarında satılması plânlanmasına ${ }^{37}$ rağmen konu değerlendirildiğinde vilayet dışında satılmasının doğru olmadığına karar verilmiştir. ${ }^{38}$

Kuzguncuk'ta bulunan Musevi erkek ve kız mekteplerinin intiyaçlarını karşılamak üzere 100.000 kuruşluk bir piyango düzenlenmesi için müracaatta bulunulmuştur. ${ }^{39}$ Öte yandan Hasköy'de bulunan Musevi mektebi yararına piyangoya konulacak eşyanın 8.550 parça ve değerinin 30.138 kuruş olduğu, 5'er kuruştan satılacak biletler ile 12.112 kuruş gelir elde edileceği belirtilmiştir. ${ }^{40}$

\footnotetext{
${ }^{36}$ BOA. Y.PRK.DH 13/13 (18 Receb 1322/28 Eylül 1904)

37 BOA. Y.PRK.DH 13/13 (18 Receb 1322/28 Eylül 1904)

${ }^{38}$ BOA. DH.TMIK.M 162/26 (21 Zilkâde 1321/8 Şubat 1904)

${ }^{39}$ BOA. MV 14/1 (12 Safer 1304/10 Kasım 1886)

40 BOA. MV 47/31 (18 Muharrem 1307/14 Eylül 1889)
}

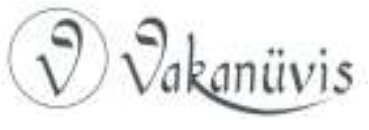


4 Temmuz 1891'de Kuruçeşme'deki Rum kız mektebi yararına piyango düzenlenmesine ruhsat verilmesi Rum mekteb ve kiliseler idaresi tarafından istenmiş, bunun için konulan eşya deftere kaydedilmiş, 5'er kuruşluk 600 bilet basılması kararlaştırılmıştır. ${ }^{41}$ Büyükçekmece'de bulunan Rum kız mektebi talebelerinin el işlerinin 5'er kuruşluk 600 adet bilet karşılığında piyangoya konulması için izin istenmiştir. Bu iznin verilmesi için öncelikle mektebin resmî ruhsatının olması, piyangoya konulacak eşyanın miktar ve çeşitleriyle değerlerinin bilinmesi, piyangonun nerede çekileceğinin tayin edilmesi, piyango mektebin ihtiyaçlarına karşıık olmak üzere düzenlenecek ise hasılatın intiyaçları karşılayıp karşılamayacağı, piyangonun zamanı ve çekilişin uygun olup olmadığının belirtilmesi de istenmiştir. ${ }^{42}$

Heybeliada'daki Rum kız ve erkek sıbyan mektepleri yararına 3.025 kuruş değerinde 59 parçadan ibaret eşya için 5'er kuruşluk 2.000 bilet basılması ve piyangonun 24 Eylül Pazar günü çekilmesi kararlaştırılmıştır. ${ }^{43}$ Çengelköy Rum mektepleri yararına 3.810 kuruş değerinde 35 parçanın konulacağı bir piyangonun düzenlenmesi ve 10.000 kuruşluk bilet basılmasına zabıtaca yapılan tahkikatta izin verilmiştir. ${ }^{44}$ Öte yandan Fener'de Ayayorgi Kilisesi'nin bünyesinde bulunan Rum kız mektebi talebelerinin el işlerinin de piyangoya konulması kararlaştırılmıştır. ${ }^{45}$

Kiremit mahallesinde bulunan Rum kız ve erkek mekteplerinin 5.560 kuruşa ihtiyaçları olduğundan 10'ar kuruşluk 400 adet bilet basılarak 4.000 kuruş karşılığında piyango düzenlenmesi ve gelecek Haziran'da mekteb salonunda çekiliş yapılması kararlaştırılmış ve gerekli izinler alınmıştır. ${ }^{46}$ Topkapı'da Eli Haralombos adlı Rum mektebi yararına düzenlenecek piyango da uygun görülürken, 15 Ağustos'da 50 parça 21 kalem eşyanın çekilişe konulacağı ifade edilmiştir. ${ }^{47}$

\footnotetext{
${ }^{41}$ BOA. Y.PRK.MF 2/15 (27 Zilkâde 1308/4 Temmuz 1891)

42 BOA. DH.MKT 260/33 (10 Muharrem 1312/14 Temmuz 1894)

${ }^{43}$ BOA. MF.MKT 364/30 (7 Rebiülevvel 1315/6 Ağustos 1897)

${ }^{44}$ BOA. MF.MKT 353/27 (25 Şevval 1314/29 Mart 1897)

45 BOA. Y.PRK.ZB 19/97 (24 Rebiülevvel 1315/23 Ağustos 1897)

46 BOA. MF.MKT 564/11 (26 Muharrem 1319/14 Haziran 1901); MF.MKT 564/47.

47 BOA. DH.EUM.THR 40/41 (28 Cemaziyelahir 1321/24 Eylül 1903)
}

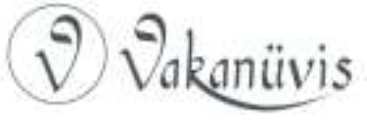




\subsection{Balo Esnasında Yapılan Piyango Çekilişleri}

Osmanlı Devleti'nin son dönemlerinde özellikle büyük kentlerde düzenlenen balolar da piyango çekilişlerine ev sahipliği yapmıştır. Örneğin, Kumkapı'da bulunan Rum mekteplerinin yıllık 38.986 kuruş kadar açığı bulunduğu ve her sene düzenlenen balo ve piyangolar ile bu açıkların kapatıldığı bilinmektedir. ${ }^{48}$ Gayrimüslim mektepler yararına her yıl kış mevsiminde başta Beyoğlu, Üsküdar, Kadıköy, Adalar, Ortaköy, Büyükdere, Fener, Kuzguncuk'ta düzenlenen bu tür balo, tiyatro ve piyangoların öncesinde ve sonrasında teftişine yönelik düzenlemeler yapılarak uygulamaya konulmuştur. ${ }^{49}$ Böylece amacının dışına çıkan balo ve organizasyonlara izin verilemeyeceği açıkça ifade edilmiştir.

Pendik Rum Ortodoks Mektebi yararına 1 Eylül 1901 Cumartesi akşamı bir balo düzenlenmesi ve balo sonunda 300'ü 5'er ve 150'si 10'ar kuruştan 3.000 kuruşluk bir piyango çekilişi yapılması kararlaştırılmıştır. ${ }^{50}$ Ayvansaray Lonca'da bulunan Rum mekteplerinin ihtiyaçlarının karşılanması için ise Fener'de Kılburnu Gazinosu'nda 23 Şubat'ta düzenlenecek balo sırasında piyango çekilişi yapılması kararlaştırılmıştır. ${ }^{51}$ Aynı şekilde Balat'da bulunan Alliance Israelite erkek mektebinde kimsesiz talebeler yararına 16 Şubat 1902'de bir balo düzenlenmesi ve balo sırasında piyango çekilişi yapılması için başvuruda bulunulmuştur. ${ }^{52}$

Fener'de erkek Rum rüştiye mektebinin bütçe açığını kapatmak için bir balo düzenlenmesi ve balo esnasında 1.400 kuruşluk piyango çekilişi yapılması kararlaştırılmıştır. Balo ve piyangonun düzenlenmesi sırasında Mekâtib-i Gayrimüslime ve Ecnebiye Müfettişlik İaresi'nden Niyazi Efendi'nin hazır bulunması, 120.000 kuruşluk bilet basılması ve bütün bunlar için ruhsatname verilmesi kabul edilmiştir. ${ }^{53}$

Bu arada Bakırköy Rum kız ve erkek mektepleri yararına düzenlenen baloda izinsiz piyango çekilişi yapıldığı yönünde gelen haberler üzerine

\footnotetext{
48 BOA. MF.MKT 211/8 (15 Zilhicce 1311/19 Haziran 1899)

49 BOA. Y.PRK.MF 1/67 (16 Cemaziyelahir 1306/17 Şubat 1889)

50 BOA. MF.MKT 578/28 (29 Cemaziyelevvel 1319/13 Eylül 1901)

${ }^{51}$ BOA. MF.MKT 602/9 (17 Şevval 1319/27 Ocak 1902)

52 BOA. MF.MKT 609/49 (12 Zilkâde 1319/20 Şubat 1902)

53 BOA. ZB 29/153 (20 Şevval 1323/18 Aralık 1905)
}

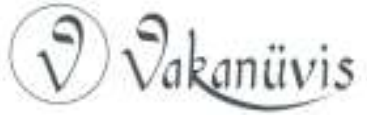


zaten 4 ay önce 6.000 kuruşluk bir tiyatroya izin verildiğinden bu durumun kabul edilemeyeceği ifade edilmiştir. ${ }^{54}$

\section{Piyangodan Elde Edilen Gelirin Kullanımı}

Piyangolardan elde edilen gelir, mekteplerin inşa ve tamirinden muallim ve talebelerin ihtiyaçlarının karşılanmasına kadar pek çok alanda kullanılmıştır. Gelir kaynakları sınırlı olan gayrimüslim mekteplerin işleyişi büyük ölçüde bu şekilde temin edilmiştir.

\subsection{Mekteplerin İnşaat ve Tamirat Masraflarının Karşılanması}

Gayrimüslim mektepler yararına düzenlenen piyangoların işlevlerinden birisi binalarının inşa ve tamirat masraflarının karşılanmasıdır. Örneğin, Şile kazasında İyos Eftemiyos kilisesine bağlı Rum kız mektebinin inşası ve diğer masrafları için 5'er kuruşluk 1.000 adet bilet basılarak bir piyango düzenlenmesi için kilise mütevellisi başvuruda bulunulurken basılan 1 bilet de numune olarak gönderilmiştir. ${ }^{55}$ Yine Şile'de Aşağı Yeniköyü'nde 200 erkek ve 100 kız talebesi bulunan Rum sıbyan mektebi harap hale geldiğinden yeniden inşası için 5 kuruş kıymetinde 2.000 adet bilet basılarak bir piyango düzenlenmesi kararlaştırılmıştır. ${ }^{56}$

Beyoğlu Çeşme Sokağı'nda yanarak harap olan ve tamir edilemeyen Ermeni Katolik cemaati kız mektebinin inşaatının tamamlanması için Ermeni patrikliği tarafından 100.000 kuruşluk bir piyango düzenlenmesi kararlaştırılmış ancak 50.000 kuruşa kadar izin çıkmıştır. ${ }^{57}$

Beyoğlu'nda Hüseyin Ağa Mahallesi'nde Lale Sokağı'nda 11 numarada bulunan Ermeni Hamazkos Kız Mektebi'nin tamiratının yanısıra fukara çocukların ihtiyaçlarını karşılamak üzere talebenin el

\footnotetext{
54 BOA. MF.MKT 352/42 (21 Şevval 1314/25 Mart 1897)

55 BOA. DH.MKT 1465/79 (7 Rebiülevvel 1305/23 Kasım 1887)

${ }^{56}$ BOA. MF.MKT 101/68 (15 Muharrem 1306/21 Eylül 1888)

57 BOA. ŞD 212/29 (29 Rebiülahir 1310/20 Kasım 1892; i.MF 1/35 28 Cemaziyelevvel 1310/18 Aralık 1892)
}

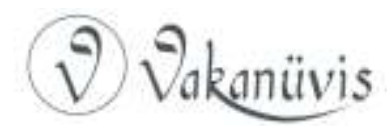


işlerinin konulacağı bir piyango düzenlenmesi ve $10^{\prime}$ ar kuruşluk 600 bilet basılması kararlaştırılmıştır. ${ }^{58}$

Eğrikapı'da bulunan Rum kız ve erkek mektebi yararına bir süredir her sene düzenlenen piyango ve tiyatroya rağmen 7 sene önce yaşanan yangınından sonra ahali dağıldığı için mektep de harap bir hale gelmiştir. Mektebin tamirat masraflarını karşılamak üzere talebenin el işlerinden 30 tanesinin piyangoya konularak 5'er kuruşluk 1.200 adet bilet basılması ve 28 Ağustos 1907'de mektep salonunda çekiliş yapılması için izin başvurusunda bulunulmuştur. Ancak mektep çok harap olduğundan çekilişin burada yapılması tehlikeli olduğu düşünülerek zabıtalar dışında en fazla 20-25 kişinin hazır bulunmasının yeterli olacağı belirtilmiştir. ${ }^{59}$

\subsection{Mekteplerin Bütçe Açığının Kapatılması}

Gayrimüslim mekteplerin gelir kaynaklarının sınırlı olması sebebi ile masraflarını karşılayamadıkları ve bütçe açıklarını kapatma gerekçesiyle zaman zaman piyango düzenlemek için başvuruda bulundukları görülmüştür. Örneğin, Hasköy'de 400 öğrencisi bulunan ve geliri giderlerini karşılamayan Musevi mekteplerinin yararına her bir numarası kazanacak şekilde bir piyango çekilişi yapılmasına izin verilmiştir. ${ }^{60}$ Fener' deki Rum kız mektebi talebelerinin maddî durumu iyi olmadığından ve alınan ücretler masraflarına yetmediğinden yarımşar Osmanlı lirası değerinde 800 adet biletten oluşan bir piyangonun düzenlenmesine de emsallerine verilen izin doğrultusunda onay verilmiştir. ${ }^{61}$

Aynı şekilde İmir'de bulunan Musevi mektebi de yeterli bütçeye sahip olmadıklarını ileri sürerek 100.000 kuruşluk bir piyango düzenlenmek için izin talep etmiştir. ${ }^{62}$ Kuzguncuk'ta 5 yıl önce açılan Musevi kız ve erkek mektebinin ihtiyaçlarını karşılayamadığından Kuzguncuk Cemaatbaşılığı ve Musevi tüccarlar tarafından yapılan

\footnotetext{
58 BOA. DH.TMIK.M 159/9 (22 Ramazan 1321/12 Aralık 1903)

59 BOA. ZB 29/71 (28 Receb 1323/28 Eylül 1905)

60 BOA. MV 38/27 (8 Rebiülahir 1306/12 Aralık 1888)

61 BOA. I.MMS 103/4358 (29 Cemaziyelevvel 1306/31 Ocak 1889); MV 39/49 (25 Cemaziyelevvel 1306/27 Ocak 1889)

62 BOA. MV 57/52 (6 Safer 1308/21 Eylül 1890)
}

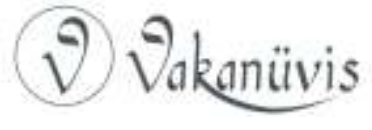


müracaat ile 100.000 kuruşluk bir piyango çekilişi yapılması kararlaştırılmıştır. ${ }^{63}$

Adana'da bulunan Ermeni Katolik kız mektebi de talebelerinin hazırladığı eşyanın piyangoya konularak geliri giderlerine yetmeyen mektebin ihtiyaçlarını karşılamaya çalışmışlardır. ${ }^{64}$

Eğrikapı Rum mektebi de aynı gerekçe ile başvuruda bulunurken ayrıntılı bir tablo ile de içinde bulundukları durumu ifade etmişlerdir.

Tablo 2. Eğrikapı Rum Mektebi'nin Gelir-Gider Tablosu ${ }^{65}$

\begin{tabular}{|l|l|}
\hline Gelirler & Kuruş \\
\hline Eğrikapı kilisesinin tahsisatı & 4200 \\
\hline Lonca ayazmasının tahsisatı & 4800 \\
\hline Duhuliye (giriş) ücreti & 3200 \\
\hline $\begin{array}{l}\text { Kiliselerden gezen talebelerden } \\
\text { gelen ücret }\end{array}$ & 3250 \\
\hline Toplam & 15.450 \\
\hline
\end{tabular}

\begin{tabular}{|l|l|}
\hline Giderler & Kuruş \\
\hline $\begin{array}{l}\text { Erkek mektebinin muallimlerinin } \\
\text { maaşı }\end{array}$ & 9000 \\
\hline Kız mektebi muallimatının maaşı & 7440 \\
\hline Hademeye verilen maaş & 960 \\
\hline Şukkaya & 240 \\
\hline Odun, kömür masrafı & 1000 \\
\hline Toplam & 18.640 \\
\hline
\end{tabular}

Gelir-gider farkı

3190

Tabloda görüldüğü üzere; 3.190 kuruşluk açığı bulunan Eğrikapı Rum Mektebi yararına 14 Temmuz Pazar günü kız öğrencilerin el işlerinden

63 BOA. ŞD 209/57 (1 Safer 1304/30 Eylül 1886)

64 BOA. MF.MKT 144/52 (3 Zilhicce 1309/29 Haziran 1892)

65 BOA. MF.MKT 306/58 (17 Ramazan 1313/2 Mart 1896)

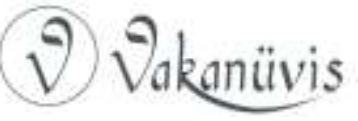


40 parçanın konulacağı bir piyango çekilişi yapılması, bunun için 5'er kuruşluk 500 adet bilet basılmasına izin verilmesi talep edilmiştir.

Beşiktaş'ta bulunan Rum mektebi yararına düzenlenecek piyangoya talebenin el işlerinden 2.000 kuruş değerinde 70 parçanın alâ, evsat ve edna olmak üzere 3 kısma ayrılarak konulması, 8.000 kuruşa ihtiyaçları olduğundan 10'ar kuruştan 800 adet biletin basılması kararlaştırılmıştır. Söz konusu mektep biri kız biri erkek olmak üzere 2 binadan oluşan ilk ve orta kısımlarından oluşmaktadır. 300 öğrencisi olup her iki tarafta 9 muallim ve muallime bulunmaktadır. Her sene 200 liradan fazla açıkları olduğundan önce bir balo düzenlenmiş ve buradan 80 lira gelir elde edilmiş ise de halen 10.000 kuruşa yakın bir ihtiyaçları olduğu görülmüştür. Bu nedenle 2.000 kuruş değerinde el işlerini piyangoya koymak üzere numuneler hazırlamışlardır. ${ }^{66}$

Balat'da Aya Istraiti Kilisesi'ne bağlı kız ve erkek mekteplerinin masraflarına karşılık bir piyango düzenlenmesi, 5'er kuruştan 1.200 adet bilet basılması, kız mektebinin salonunda yapılacak piyango çekilişine 2.000 kuruş değerinde 50 parça el işinin konulması kararlaştırılmıştır. İşlenmiş nene gömleği, fistan fistosu, karyola yastığı, sofra havlusu, iplikli yastık, çukadan işlemeli halı, gazete koymak için iplikli çanta, kart ve vizite koymak için çanta, küçük sofa halısı, çukadan takım örtüsü, saat kesesi, kart ve vizite için küçük kutu, işlemeli saksı içinde çiçek bunlardan bazılarıdır. ${ }^{67}$

Kumkapı Rum mekteplerinin 20.000 kuruşluk açığını kapatmak üzere 6 Eylül Pazar günü talebelerin el işlerinin konulacağı bir piyango düzenlenmesi kararlaştırılırken ayrıntılı bir cetvel de hazırlanmıştır.

Tablo 3. Kumkapı Rum Mektepleri Hasılat Cetveli ${ }^{68}$

\begin{tabular}{|l|l|}
\hline Hasılat & Kuruş \\
\hline $\begin{array}{l}\text { Erkek mektebi talebesinden alınan } \\
\text { duhuliye ücreti }\end{array}$ & 16.800 \\
\hline $\begin{array}{l}\text { Kız mektebi talebesinden alınan } \\
\text { duhuliye ücreti }\end{array}$ & 8.300 \\
\hline
\end{tabular}

${ }^{66}$ BOA. MF.MKT 272/26 (11 Muharrem 1313/4 Temmuz 1895)

67 BOA. MF.MKT 322/17 (13 Muharrem 1314/24 Haziran 1896)

68 BOA. MF.MKT 512/16 (6 Rebiülevvel 1318/4 Temmuz 1900)

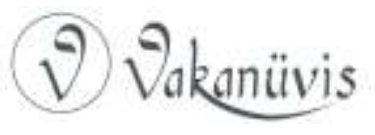




\begin{tabular}{|l|l|}
\hline $\begin{array}{l}\text { Sıbyan mektebi talebesinden alınan } \\
\text { duhuliye ücreti }\end{array}$ & 7.750 \\
\hline Meryem Ana kilisesi tahsisatı & 12.000 \\
\hline Ayayorgi kilisesi tahsisatı & 12.000 \\
\hline Zafiripulus vasiyeti & 5.898 \\
\hline Kutu hasılatı & 2.700 \\
\hline İanat-ı müteferrika-i fevkalâde & 3.424 \\
\hline Toplam & 68.872 \\
\hline Açık & 20.000 \\
\hline & 88.872 \\
\hline
\end{tabular}

Benzer şekilde Ortaköy kız ve erkek mekteplerinin 155 liralık açığının kapatılması için talebelerin el işlerinin konulacağı bir piyango düzenlenmesi ve bunun için 5'er kuruştan 3.000 adet biletin basılması talep olunmuştur. ${ }^{69}$

Söz konusu isteklerle ilgili arşivde pek çok belge mevcuttur. Nitekim Edirnekapısı civarında Sarmaşık Mahallesi'nde bulunan kız ve erkek mekteplerinin bütçe açığının kapatılması için talebenin el işlerinden 30 adet eşyanın piyangoya koyularak 5 'er kuruşluk biletler basılması ve piyangonun 8 Kasım 1906 Perşembe günü mektebin salonunda çekilmesi kararlaştırılmıştır. ${ }^{70}$

Beykoz kazası Arnavud karyesinde bulunan Rum kız ve erkek mekteplerinin 3.600 kuruş açığı bulunduğu, intiyaçlarını karşılamak üzere kız talebelerin el işlerinin konulacağı ve erkek mektebi salonunda çekilecek piyango için Kadıköy Rum metropolitliği başvuruda bulunmuştur. ${ }^{71}$

14 Eylül 1904 tarihinde Burgaz adası Rum mektebinin açığını kapatmak üzere talebenin el işlerinden 80 adetinin konulacağı 10.000 kuruşluk bir piyango çekilişi yapılması ve çekilişe Fuad Efendi'nin nezaret etmesi kararlaştırılmıştır. ${ }^{72}$

\footnotetext{
${ }^{69}$ BOA. MF.MKT 563/28 (24 Safer 1319/12 Haziran 1901)

70 BOA. ZB 29/7 (22 Cemaziyelevvel 1322/4 Ağustos 1904)

${ }^{71}$ BOA. DH.TMIK.M 181/12 (22 Cemaziyelahir 1322/3 Eylül 1904)

72 BOA. ZB 380/31 (11 Receb 1322/21 Eylül 1904)
} 
Kadıköy'de Taras Varidi isimli Rum kız mektebi müdiresi tarafından verilen arzuhalde; resmî ruhsatı bulunan mekteplerinin 20.000 kuruşluk bütçe açıkları bulunduğu belirtilerek bütçe ve eşyalarının kıymet ve miktarını gösteren pusula ve defterler takdim edilmiştir. Bütçe açığını kapatmak için talebenin el işlerinden 30 adet eşyanın piyangoya konulması ve piyangonun 13 Ekim 1907 Pazar günü okulun salonunda çekilmesi kararlaştırılmıştır. ${ }^{73}$

Kuzguncuk Rum erkek mektebi mütevellisi Dimustufli Yakumerbidi imzasıyla gönderilen arzuhal, lane-i Mekâtib Komisyonu'na havale edildiğinde mektebin resmi ruhsata sahip olduğu ve gelirinin masrafını kapatamadığı anlaşılmıştır. 8.000 kuruş açığı bulunan mektep için talebenin el işlerinden 45 adet eşyanın piyangoya konulması ve bunun için 10.000 kuruşluk bilet basılması ve dağıtılmasıyla piyangonun 8 Aralık 1907 Pazar günü mektep salonunda çekilmesine izin verilmiştir. ${ }^{74}$

Cibali Rum kız ve erkek mekteplerinin 7.520 kuruşluk açığının kapatılması için kız talebelerin el işlerinden 50 adetinin konulacağı ve 6 Temmuz 1908 günü çekilecek bir piyango düzenlenmesi, tanesi 5 kuruştan 1.500 bilet basılarak 7.500 kuruş toplanması hedeflenmiştir. Nitekim bir önceki sene düzenlenen piyangoda toplanan 4.000 kuruş muallimlerin maaşına sarf edilmiştir. ${ }^{75}$

Boğaziçi'nde Yenimahalle'deki Rum mektebinin 13.000 kuruş açığının kapatılması için talebenin el işlerinden 40 adeti ile bir piyango düzenlenmesi kabul edilmiştir. ${ }^{76}$ Aynı şekilde Darıca'da ki Rum mekteplerinin bütçe açığının kapatılması için $5^{\prime}$ er kuruşluk biletler ile 10.000 kuruşluk bir piyango düzenlenmesi, 120 adet el işinin piyangoya konulması kararlaştırılmıştır. ${ }^{77}$

Üsküdar Ortodoks mektebinin günden güne artan ihtiyaçlarını ve açıklarını kapatmak üzere de talebenin 60 adet el işlerinin konulacağı bir

\footnotetext{
73 BOA. ZB 29/73 (3 Rebiülahir 1323/7 Haziran 1905)

74 BOA. ZB 29/136 (17 Şaban 1323/17 Ekim 1905)

75 BOA. MF.MKT 1052/79 (6 Rebiülahir 1326/8 Mayıs 1908); ZB 340/20 (10 Rebiülevvel 1326/ 12 Mayıs 1908)

76 BOA. MF.MKT 1053/74 (10 Rebiülahir 1326/12 Mayıs 1908)

77 BOA. MF.MKT 1012/70 (11 Recep 1325/20 Ağustos 1907)
}

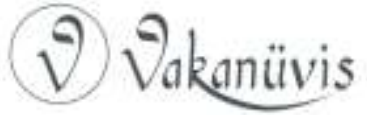


piyango düzenlenmesi, beheri 5'er kuruştan 2.000 adet bilet basılması ve 3 Temmuz 1907 günü çekiliş yapılması uygun görülmüştür. ${ }^{78}$

Öte yandan Beykoz'da bulunan Ermeni ibtidai mektebinin bütçe açığını kapatmak üzere mükafat dağıtım töreni sırasında piyango düzenlenmesi için izin talep edilmiştir. ${ }^{79}$

\subsection{Mektep Muallimlerinin Maaşlarının Temini}

Mekteplerin gider kalemlerinden birisi de muallimler başta olmak üzere görevlilerin maaşlarının karşılanması olup piyango başvurusunda bulunulurken bu da gerekçe olarak sunulmuştur. Örneğin, Heybeliada'da bulunan Rum kız ve erkek sıbyan mektebinin muallimlerinin maaş ve masrafları için 6.000 kuruşa ihtiyaç olduğu, bunun için 5'er kuruşluk 1.200 adet bilet bastırılması için ruhsat talebinde bulunulmuş ancak yanlışlık yapıldığından yalnız 200 adet bilet basımına izin çıkmıştır. ${ }^{80}$

Benzer şekilde Silivri Bigados karyesi Rum kız mektebinin muallim maaşları ${ }^{81}$ ile Cibali Rum kız ve erkek mektepleri muallimlerinin maaşına sarf edilmek üzere piyangolar düzenlenmiştir. ${ }^{82}$

Arnavutköy Rum kız ve erkek mektebinin hiçbir yerden geliri olmadığı ifade edilerek 3.000 kuruşu geçen muallim ve kalfa maaşlarının karşılanması için 5'er kuruştan 600 adet bilet bastırılarak bir piyango düzenlenmesi için başvuruda bulunulmuştur. Bu mümkün olmaz ise mektebin eğitime devam edemeyeceği belirtilirken piyangoya konulacak 731 kuruş değerinde kadife terlik, işleme yastık, gömlek, yün boyun atkısı, tütün mahfazası gibi eşyaların Osmanlıca ve Rumca olmak üzere listesi de sunulmuştur. ${ }^{83}$

Şile'de kız ve erkek Hıristiyan ibtidai mekteplerinin masrafları o zamana kadar kiliselerinin yardımıyla karşılanmakla birlikte özellikle son

\footnotetext{
78 BOA. MF.MKT 993/62 (16 Rebiülevvel 1325/29 Nisan 1907)

79 BOA. MB.ïT 241/8 (11.08.1327/28 Ağustos 1909)

80 BOA. DH.TMIK.M 73/7 (9 Rebiülevvel 1317/18 Temmuz 1899)

81 BOA. DH.TMIK.M 247/16 (8 Cemaziyelevvel 1325/19 Haziran 1907)

82 BOA. MF.MKT 1052/79 (6 Rebiülahir 1326/8 Mayıs 1908)

83 BOA. MF.MKT 224/42 (7 Rebiülevvel 1312/8 Eylül 1894)
}

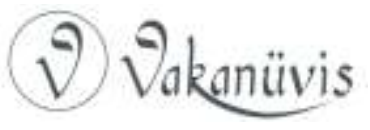


zamanlarda balık ihracatı ile geçimini sağlayan kazada bu konuda yaşanan sıkıntıların buraya da yansıdığı ifade edilmiştir. 300 civarında talebeyi barındıran mektebin muallim ve muallime maşlarının ödenebilmesi için 8.000 kuruş kıymetinde 2.000 biletin basılması kararlaştırılmıştır. ${ }^{84}$

Tablo 4. Şile Kız ve Erkek Hıristiyan İbtidai Mektebi'nin Muallim ve Muallime Maaşları ${ }^{85}$

\begin{tabular}{|l|c|c|}
\hline \multicolumn{1}{|c|}{ Masraf Kalemi } & $\begin{array}{c}\text { Aylık maaş } \\
\text { (kuruş) }\end{array}$ & $\begin{array}{c}\text { Yıllık maaş } \\
\text { (kuruş) }\end{array}$ \\
\hline 1. Muallimin maaşı & 540 & 6480 \\
\hline 2. Muallimin maaşı & 270 & 3240 \\
\hline 3. Muallimenin maaşı & 400 & 4800 \\
\hline 4. Muallimenin maaşı & 200 & 2400 \\
\hline $\begin{array}{l}\text { Iki mektebin mefruşat ve } \\
\text { mahrukat masrafı }\end{array}$ & 100 & 1200 \\
\hline \multicolumn{1}{|c|}{ Toplam } & 1.510 & 18.120 \\
\hline
\end{tabular}

\subsection{Talebelerin İhtiyaçlarının Karşılanması}

Mektep yararına düzenlenen piyangoların başlıca gayelerinden birisi de özellikle yoksul talebelerin kitap ve kıyafet başta olmak üzere temel intiyaçlarının karşılanmasıdır. Belgelerde bu konuda pek çok örnek mevcuttur.

İzmir Musevileri, İzmir'de bulunan yoksul çocukların eğitimlerine devam etmeleri ve iyi yetişmeleri için Mekteb-i Terakki ismiyle bir mektep açmışlardır. Ancak mektebin masraflarına karşılık olmadığından fukara çocuklarının ücretsiz olarak eğitim almaları için yardıma desteğe ihtiyaç duyulmuştur. Bu yardımlar ile mektebi idare mümkün olmadığından bir taraftan borçlar artmakta bir taraftan da maddî sıkıntılar nedeniyle mektebin kapanması gündeme gelmektedir. Mektebin idare ve eğitimi ile ilgilenen komisyon böyle hayırlı bir işin devam ettirilemeyip birçok fakir çocuğun mektepsiz kalmasına gönlü razı olmadığından 3 senede sarf edilmek suretiyle 23.997 adet piyango

${ }^{84}$ BOA. MF.MKT 403/16 (12 Safer 1316/15 Ağustos 1894)

85 BOA. MF.MKT 403/16 (12 Safer 1316/15 Ağustos 1894)

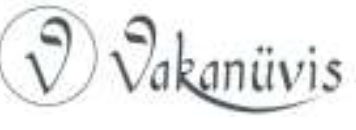


bileti bastırıp, senede 7.999 'unun arzu edenlere satılarak piyango çekilişi yapılmasını kararlaştırmıştır. Nafia ve Ticaret Nezareti ile görüşülerek mektebin kapatılmaması için bundan başka çare olmadığı ve piyangoyu düzenleyecek heyetin emin olmasıly beraber heyet-i ruhaniyenin ve hükümetin nezaretinde olması yalnız 100.000 kuruşluk bir piyangonun mektebe yetmeyeceğini ifade etmişlerdir. Piyangonun toplamı 1.900.000 kuruş nispetinde görülmüş ise de buradan 300.000 kuruştan fazla bir şey kalmayacağı, çocukların sokaklarda sefil ve sergerde gezmekten kurtarılması için bu 300.000 kuruşun mektebe kalması kalanın ikramiye olarak verilmesi öngörülmüştür. ${ }^{86}$

Ermeni Katolik cemaati rahibeleri tarafından idare edilen İzmir'deki fukara kız mektepleri için cemaat arasında dağıtılmak ve satılmak üzere 10 'ar kuruşluk 3000 adet piyango bileti basılmasına ruhsat verilmesi Ermeni patrikliği tarafından talep olunmuştur. Ermeni milletine mensup leyli ve nehari (gece ve gündüz) 3 mektebin masrafı ileri gelenlerin yardımı ile karşılanmaya çalışılmakta ise de ihtiyaçlara yetmediğinden talebenin işlerinin piyangoya konulması uygun görülmüştür. Piyango çekilişinde Maarif Nezaretinden bir memur bulunmak üzere ruhsat verilmesi kararlaştırılmıştır. ${ }^{87} 4$ yıl sonra aynı okullar için benzer bir istek de daha bulunulmuştur. ${ }^{88}$

Bilecik Katolik Azaryan Mektebi muallimesi tarafından yapılan başvuruda; mektebe devam edecek yoksul çocuklara yardım gayesiyle 2.000 kuruşluk bir piyango için izin istenmiş, Ertuğrul Mutasarrıflığı'ndan alınan bilgiler doğrultusunda gerekli ruhsat verilmiştir. ${ }^{89}$

Ortaköy kız ve erkek Rum mektebinde eğitim gören 210'dan fazla yoksul talebenin temel ihtiyaçları için 5'er kuruşluk biletler basılarak 155 liranın elde edilmesi amacıyla 50 adet el işlemesinin konulacağı bir piyangonun düzenlenmesi kararlaştırılmıştır. ${ }^{90}$

\footnotetext{
${ }^{86}$ BOA. ŞD 2949/26 (24 Muharrem 1309/30 Ağustos 1891)

87 BOA. MV 54/1 (26 Ramazan 1307/16 Mayıs 1890)

88 BOA. DH.MKT 246/40 (3 Zilhicce 1311/ 7 Haziran 1894)

89 BOA. DH.TMIK.M 41/82 (29 Cemaziyelevvel 1315/ 26 Ekim 1897)

90 BOA. MF.MKT 563/28 (24 Safer 1319/12 Haziran 1901)
}

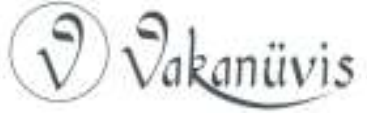


Beyoğlu'nda Aya Konstantinos kilisesinin bahçesindeki Rum kız mektebine devam eden yoksul ve yetim kızların elbise ve ayakkabı ihtiyaçları için bir piyango düzenlenmesine izin talebinde bulunulmuş ancak mektebin resmi bir ruhsatı olmadığından önce ruhsat alması gerektiği ifade edilmiştir. ${ }^{91}$ Benzer şekilde Edirne Rum mektepleri talebelerinin elbise ve ayakkabı intiyaçlarını karşılamak üzere de talebenin el işlerinin konulacağı bir piyango düzenlenmiştir. ${ }^{92}$

\section{Piyango Çekilişi İ̧̧in Şartların Uygunluğu}

Mektep yararına düzenlenen piyango çekilişleri genellikle mektep salonunda yapılmakta ve güvenlik başta olmak üzere gerekli önlemler alınmaktadır. Örneğin, Kumkapı Rum mektepleri yararına 6 Eylül Pazar günü bir piyango düzenlenmesi kararlaştırılırken çekiliş yapılacak mektep salonunun sağlam olup olmadığının Şehremaneti'nce kontrol edilip İstanbul Polis Müdüriyetince bildirilmesi istenmiştir. ${ }^{93}$ Aynı şekilde Büyükdere'deki Ermeni kız mektebi yararına piyango düzenlenmesi için verilen arzuhal Beşiktaş Polis Müdüriyeti tarafından incelenmiştir. ${ }^{94}$

Bir başka örnekte, Kuruçeşme'deki Rum kız mektebinin talebelerinin bazı el işlerinin konulacağı bir piyango düzenleneceği ve buraya Rum ahalisinden birçok kişi geleceğinden herhangi bir vukuat meydana gelmemesi için gerekli tedbirlerin alınması ve bunun için görevlilerin istihdamı istenmiştir. ${ }^{95}$

Kumkapı'da Ermeni Patrikhanesi bitişiğinde bulunan Ermeni Milli Mektebi yararına mekteb salonunda çekilişine izin verilen piyangonun, mektebin yakın zamanda meydana gelen depremden zarar gördüğü gerekçesiyle Patrikhane kilisesinin kadınlara mahsus bölümünde düzenlenmesi kararlaştırılmıştır. ${ }^{96}$

\footnotetext{
91 BOA. MF.MKT 143/12 (15 Zilkâde 1309/11 Haziran 1892; ŞD 212/10)

92 BOA. DH.TMIK.M 159/48 (14 Şevval 1321/3 Ocak 1904)

93 BOA. MF.MKT 512/16 (3 Rebiülahir 1318)

${ }^{94}$ BOA. DH.MKT 1662/10 ( 5. Safer 1307/1 Ekim 1889)

95 BOA. Y.PRK.ŞH 3/91 (7 Muharrem 1309/13 Ağustos 1891)

96 BOA. MF.MKT 246/58 (1. Şaban 1312/28 Ocak 1895)
}

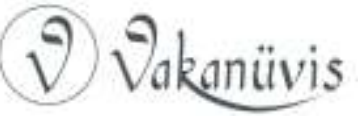


Öte yandan Beşiktaş'ta ki Rum mektebi yararına Leski isimli yerde yapılacak piyango çekilişi mahzurlu olduğundan Köyiçi'ndeki Rum kilisesi bitişiğindeki okulda çekilmesi kararlaştırılmıştır. ${ }^{97}$

\section{1. Piyango Çekilişinin Ertelenmesi veya Yasaklanması}

Mektep yararına düzenlenen piyangoların zaman zaman ertelendiği veya yasaklandığı da bilinmektedir. Şartların uygunsuzluğu veya ortaya çıkan bazı gelişmeler bu durumlara sebebiyet vermiştir. Erteleme isteği piyangoyu düzenleyen taraftan gelirken yasaklama devlet eliyle yapılmaktadır. Piyango çekilişlerinin erteleme ve değişiklik isteklerinin öncelikle Şehremaneti ve Zaptiye Nezareti'ne bildirilmesi gereklidir. Örneğin Kuzguncuk Rum mektebi yararına düzenlenecek piyangonun biletleri satılamadığından gelecek yıl 29 Aralık Pazar gününe ertelenme isteği Şehremaneti ve Zaptiye Nezareti'ne bildirilmiştir. ${ }^{98}$

Piyango çekilişinin ertelenmesinin başlıca sebebi biletlerin yeterince satılamamış olmasıdır. Örneğin Langa-i Kebir Rum mekteplerinin 20.000 kuruş açığına karşııık düzenlenmesine izin verilen 10.000 kuruşluk piyangonun biletleri 12 Ocak 1901 tarihine kadar satılamamış olduğundan 2 Haziran 1901 tarihine ertelenmiştir. ${ }^{99}$ Ancak bu tarihte de hedefe ulaşılamadığından 21 Temmuz 1902'ye ertelenmesi kararlaştırılmıştır. ${ }^{100}$

Kumkapı Rum çocuk mektepleri yararına düzenlenmesine izin verilen piyangonun 17 Şubat 1901'de düzenlenmesi plânlanmış ise de biletlerin birçoğu satılamamış olduğundan 28 Nisan 1901 tarihine ertelenmiştir. ${ }^{101}$ Kuzguncuk Rum mektebinin bütçe açığını kapatmak üzere talebelerin el işlerinin piyangoya konularak 8.000 kuruşluk bilet basılması ve 8 Aralık 1905'de çekiliş yapılması kararlaştırılmış ise de mektep mütevellilerinin başvurusu ile 20 Ocak Pazar gününe ertelenmiştir. ${ }^{102} 7$ Temmuz 1907 'de 6.000 kuruşluk piyangoya ruhsat

\footnotetext{
97 BOA. MF.MKT 272/26 (15 Muharrem 1313/8 Temmuz 1895)

98 BOA. MF.MKT 540/27 (18 Şaban 1316/1 Ocak 1899)

99 BOA. MF.MKT 551/11 (21 Zilhicce 1318/11 Nisan 1901)

100 BOA. MF.MKT 566/7 (12 Rebiülevvel 1319/29 Haziran 1901)

101 BOA. MF.MKT 549/30 (9 Zilhicce 1318/30 Mart 1901)

102 BOA. ZB 29/159 (30 Zilkâde 1323/26 Ocak 1906)
}

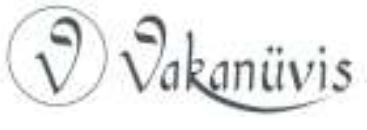


verilmesine rağmen gelecek sene 15 Temmuz'a ertelenmesi kararlaştırılmıştır. ${ }^{103}$ Samatya'da Mirahur mahallesinde bulunan Rum kız mektebi yararına 10 Kasım 1907 Pazar günü mekteb salonunda düzenlenecek piyango biletler satılamadığından (4430 kuruş satılamamıştır) gelecek sene 8 Aralık'a ertelenmiştir. ${ }^{104}$

Cibali Rum Mektebi yararına 14 Temmuz 1908'de düzenlenecek piyango da aynı gerekçe ile gelecek sene 14 Eylül'e ertelenmiştir. ${ }^{105}$ Aynı şekilde Boğaziçi'nde Kuruçeşme Rum mektebi yararına 30 Ağustos 1908 de çekilişine izin verilen piyango 1 sene sonrasına, ${ }^{106}$ Beşiktaş Köyiçi mahallesindeki Rum kız mektebi yararına düzenlenen piyango gelecek sene 13 Temmuz'a ${ }^{107}$, Balat'da bulunan Aya Istrati Rum mektebi yararına yapılacak piyango çekilişi de gelecek sene 3 Şubat Pazar gününe ertelenmiştir. ${ }^{108}$

Erteleme konusunda başka sebeplerin gerekçe gösterildiği de olmuştur. Örneğin, Üsküdar Rum mektepleri yararına düzenlenen piyango, Üsküdar Ortodoks kiliseleri mütevelli heyetinin istifası nedeniyle yeni heyetin seçilip göreve başlamasından sonra çekilecektir. ${ }^{109}$ Kuzguncuk Rum kız mektebi yararına düzenlenen piyango ise çekilişten birkaç gün önce gerçekleşen deprem nedeniyle ertelenmiştir. ${ }^{110}$

Piyango çekilişlerinin ertelenmesi dışında zaman zaman yasaklar da söz konusu olmuştur. Örneğin, Adana Ermeni mekteplerinin müdürleri gelirleri masraflarını karşılayamadığından 300 mecidiyelik bir piyango düzenlenmesine izin verilmesini talep etmişler ancak buna izin verilmediği gibi yardımın iane biletleri ile toplanması istenmiştir. ${ }^{111}$

Çorlu kız mektebine yardım amacı ile (Çorlu kazasına bağlı Terkos nahiyesi Istrumca karyesi ondalık memuru Arastutil Efendi tarafından)

\footnotetext{
103 BOA. MF.MKT 1008/51 (11 Cemaziyelahir 1325/22 Temmuz 1907)

104 BOA. MF.MKT 1009/75 (16 Cemaziyelahir 1325/27 Temmuz 1907)

105 BOA. MF.MKT 1064/56 (7 Cemaziyelahir 1326/7 Temmuz 1908)

106 BOA. MF.MKT 1068/35 (5 Receb 1326/3 Ağustos 1908)

107 BOA. MF.MKT 361/9 (14 Safer 1315/15 Temmuz 1897)

108 BOA. MF.MKT 602/50 (22 Şevval 1319/1 Şubat 1902)

109 BOA. ZB 340/32 (8 Cemaziyelevvel 1324/30 Haziran 1906)

110 BOA. MF.MKT 229/7 (27 Rebiülevvel 1312/28 Eylül 1894)

111 BOA. DH.MKT 267/29 (29 Muharrem 1312 /2 Ağustos 1894)
}

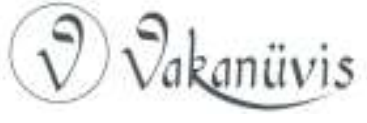


satılan piyango biletlerinin Ereğli Rum metropolitliği idaresinde bulunan köy ve kasabalardaki kilise ve mektep mütevellileri tarafından tertip edildiği anlaşıldığından biletlerin sattırılmaması için patrikhane vasıtasıyla metropolitliğe tebligat yapılması ve bu hususta gerekli tahkikatın yapılması istenmiştir. ${ }^{112}$

Eskişehir'de Fransız rahibeleri tarafından idare edilen mektep yararına düzenlenen Fransızca ibareli ve sarı kağıtlı piyango biletlerinin 23 adedi tren ile Mabeyn-i Hümayun Başvekâleti'ne gönderilmiş, 3 Mayıs'da çekilişin yapılması düşünülmüş ancak resmi ruhsatı olmadığı ve biletler üzerinde mühür olmadığı için biletlerin satışı engellenmiştir. ${ }^{113}$

Sisam'da bulunan Maver Dinios isimli sanayi mektebi menfaatine çıkarılan piyango biletlerinin sadece ada dahilinde satılmasının mümkün olduğu belirtilerek 50.000 kuruşa kadar buna müsaade edileceği de ifade edilmiştir. ${ }^{114}$ izmir Karşıyaka'da Ayaanna isimli Rum kilisesinin masrafına karşılık olmak üzere düzenlenen piyango biletlerinin Eskişehir'de satılması ve bir tanesinin gönderilerek ihbarda bulunulması üzerine Zaptiye Nezareti ve Hüdavendigar vilayetine bilgi verilerek gibi vilayet dışında satılmasına izin verilmemesi istenmiştir. ${ }^{115}$

Zaman zaman devlet müdahalesiyle bazı değişiklikler de gündeme gelmiştir. Örneğin, İzmir'de sanayi ve Musevi mektepleriyle, Selanik piyangoları devletçe menedilerek yerine Ziraat Bankası tarafından bir piyango tesisi kararlaştırılmıştır. ${ }^{116}$ İmir'de bulunan Mekteb-i Sanayi ile Yahudi mektebi namına düzenlenen piyangoların Hicaz demiryolu menfaatine tahvili kararlaştırılmıştır. ${ }^{117} \mathrm{Bu}$ arada gayrimüslim mektepler yararına düzenlenen piyangolar (balo ve tiyatrolar da dahil olmak üzere) için verilen ruhsatnamelere Hamidiye-Hicaz Demiryolu yararına birer kuruşluk ilmühaber yapıştırılması istenmiştir. ${ }^{118}$

\footnotetext{
112 BOA. DH.TMIK.M 82/51 (26 Zilkâde 1317/28 Mart 1900)

113 BOA. DH.TMIK.M 141/41 (11 Muharrem 1321/9 Nisan 1903)

114 BOA. A.MTZ.SM 3/136 (16 Cemaziyelevvel 1329/15 Mayıs 1911)

115 BOA. DH.TMIK.M 274/88 (29 Zilhicce 1326/22 Ocak 1909)

116 BOA. I.TNF 15/14 (16 Safer 1324/20 Ocak 1906)

117 BOA. Y.EE.KP 27/2675 (3 Muharrem 1324/27 Şubat 1906)

118 BOA. MF.MKT 828/49 (22 Zilkâde 1322/28 Ocak 1905)
}

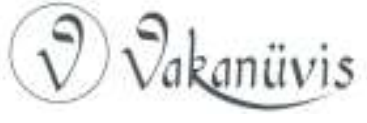


İzmir'de tesis ve inşa olunan Musevi mektebinin menfaatine olmak üzere 1.900 .160 kuruşluk bir piyangoya ruhsat verilmesi için İzmir hahambaşılığından verilen takrir üzerine; İzmir Musevi mektebinin ihtiyaçlarını karşılayacak imkanların olduğundan sadece 100.000 kuruşluk piyango çekilişine izin verildiği görülmüştür. ${ }^{119}$

Yedikule'de bulunan Ermeni kız ve erkek eytam okulları yararına 20 kuruşluk 2.000 bilet basılması kararlaştırılmış olmakla birlikte resmî ruhsatının olmadığı anlaşıldığından öncelikle bu meselenin halledilmesi gerektiği ifade edilmiştir. ${ }^{120}$

Ankara'da Rum kız mektebi yararına düzenlenen piyangoya Ankara Maarif Müdürlüğü izin vermekle birlikte piyangonun nasıl çekildiği, ahaliden nasıl para toplandığı ve hangi eşyaların piyangoya konulup kaç bilet dağıtıldığı bilinmediğinden bu konularda hükümet ve nezarete sorulmadan karar verilmesi mümkün olmadığından ihtarda bulunulmuştur. ${ }^{121}$

\section{Piyangolarda Yaşanan Suistimaller}

Mektep yararına düzenlenen piyangolarda kurum veya kişilerin yaptığı çeşitli uygunsuzluk ve suiistimaller de yaşanmıştır. Bunlar tespit edildiğinde gerekli müdahalelerde bulunulmuştur. Örneğin, Kuzguncuk Musevi mektebi yararına düzenlenen 100.000 kuruşluk piyangonun düzenlenmesinde mektep mütevellilerinin suiistimali üzerine değiştirilmeleri ve yerlerine yenilerinin seçilmesi istenmiştir. ${ }^{122}$

İzmir'de Musevi mektebi yararına ruhsatsız olarak düzenlenen piyangodan 3.799.000 kuruş gelir elde edildiği anlaşılınca bu miktara el konulmasına karar verilmiştir. ${ }^{123}$ Ruhsatsız olmasının yanısıra birkaç milyon kuruşluk bir piyango çekilişinin mümkün olmadığı ifade edilmiştir. ${ }^{124}$

\footnotetext{
119 BOA. MV 57/52 (6 Safer 1308/21 Eylül 1890)

120 BOA. DH.TMIK.M 175/38 (14 Rebiülahir 1322/28 Haziran 1904)

121 BOA. MF.MKT 329/62 (5 Rebiülevvel 1314/14 Ağustos 1896)

122 BOA. MF.MKT 150/25 (22 Safer 1310/15 Eylül 1892)

${ }^{123}$ BOA. DH.MKT 1371/47 (12. Muharrem 1374/11 Ekim 1886)

${ }^{124}$ BOA. DH.MKT 1366/98 (21 Zilhicce 1303/20 Eylül 1886)
} 


\section{Sonuç}

Osmanlı Devleti'nin son dönemlerinde yardım amaçlı piyangoların uygulama alanlarından birisi de gayrimüslim mektepleri olmuştur. Gayrimüslim tebaa içerisinde her millet ve cemaat kendi bünyesindeki mektepler adına bu girişimde bulunmuştur. Öyle ki piyangolar zamanla bu mekteplerin gelir kaynaklarından birisi haline gelmiştir.

Piyango için öncelikle devletten izin alınması gerekliydi. Ruhani lider, mütevelli, cemaat mensupları yada mektep müdür veya idarecilerinden birinin başvurusundan sonra süreç başlamaktaydı. Bundan sonra mektebin ruhsatının olup olmadığı araştırılırdı. Piyangoya konulacak el işlerinin değerinin piyango miktarının dörtte biri derecesinde olması, piyangoya konulacak eşyanın cinsi, miktarı ve kıymetini gösteren bir defterin tutulması ve eşyalardan birkaç numunenin de gönderilmesi istenirdi. Piyango için basılan biletlerin Maarif Nezaretince onaylanması gerekmekteydi.

Başvuru ve düzenleme ile ilgili sözkonusu şartları taşıyan mekteplere yapılan incelemeler sonucu izin verilmiştir. "Mekâtib-i Gayrimüslim ve Ecnebiye Müfettişliği" de çekilişlere nezaret etmiştir. Arşivde konu ile ilgili pek çok belge bulunmakla birlikte Rumların birinci sırada yer aldığı görülmektedir. Ermeni ve Musevi mektepleri de onları izlemektedir.

Mekteplerin inşa ve tamirat masrafları, bütçe açıklarının kapatılması, muallimlerin maaşlarının ödenmesi ve talebelerin ihtiyaçlarının karşılanması gibi gerekçelerle düzenlenen piyangolarda kız talebelerin el işleri (işlemeler, küçük eşyalar ve kıyafetler) alâ-evsat-ednâ olarak derecelendirilerek piyangoya konulmuştur. Mektep bünyesindeki salonlarda yapılan çekilişler aynı zamanda kendi içlerindeki birlik ve beraberliğin de bir göstergesi olmuştur.

Osmanlı bünyesinde çok uzun yıllar faaliyetlerini sürdüren gayrimüslim mektepler, büyük devletler ve misyoner teşkilatları tarafından da desteklenmekle birlikte piyango düzenlemekten vazgeçmemişlerdir.

\section{(2) Vakaniuivis}




\section{Kaynakça}

Arşiv Belgeleri

Cumhurbaşkanlığı Osmanlı Arşivi

A.MTZ.SM. 3/136

DH.EUM.THR. 40/41

DH.HMŞ 16/73

DH.MKT. 246/40, 260/33, 267/29, 1366/98, 1371/47, 1465/79, 1662/10

DH.MKT.M. 247/16, 1366/98, 1371/47,

DH.TMIK.M. 41/82, 73/7, 82/51, 138/47, 141/41, 159/9, 159/48, 162/26, $175 / 38,181 / 12,247 / 16,274 / 88$

i. HR $113 / 5514$

I.MMS. $103 / 4358$

I.TNF. 15/14

MB.їBT. 241/8

MF.MKT. 101/68, 115/26, 143/12, 144/52, 150/25, 158/39, 211/8, 224/42, 229/7, 246/58, 262/38, 272/26, 306/58, 322/17, 329/62, 346/30, 346/35, $346 / 50,352 / 42,353 / 27,358 / 27,361 / 9,364 / 30,403 / 16,512 / 16,540 / 27$, $549 / 30,551 / 11,563 / 28,564 / 11,564 / 47,566 / 7,578 / 28,602 / 9,602 / 49$, 609/50, 828/49, 928/47,967/8, 993/62, 1007/60, 1008/51, 1009/75, 1012/70, $1052 / 79,1053 / 74,1064 / 56,1068 / 35$,

MV. $14 / 1,38 / 10,38 / 27,39 / 49,47 / 31,54 / 1,57 / 52,76 / 42$

ŞD. 209/57, 212/10, 212/29, 2949/26

TS.MA.e. $1385 / 45$

Y.EE.KP. 27/2675

Y.PRK.DH. 13/13

Y.PRK.MF. 1/67, 2/15

Y.PRK.ŞH. 3/91

Y.PRK.ZB. $19 / 97$

ZB. 28/6, 29/7, 29/71, 29/73, 29/136, 29/153, 29/159, 340/20, 340/22, $340 / 31,340 / 32,380 / 31$

\section{Kitap ve Makaleler}

Ebuzziya Tevfik, "Piyango", Mecmua-yı Ebuzziya, Gurre-i Safer 1300, C.3, N.27.

Haydaroğlu Polat, ilknur, Osmanlı Imparatorluğu'nda Yabancı Okullar, Ankara, 1990, Kültür Bakanlığı Yay.

Tunçay, Mete, Türkiye'de PiyangoTarihi ve Millî Piyango Idaresi, Ankara, 1993.

Vahapoğlu, Hidayet, Osmanlı'dan Günümüze Azınlık ve Yabancı Okulları (Yönetimleri Açısından), Ankara, 1990.

Yeşil, Fatih, Aydınlanma Çağında Bir Osmanlı Kâtibi Ebubekir Ratib Efendi (1750-1799), İstanbul, 2010.

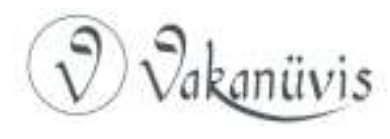

